\title{
Quantitative characteristics of the neurotensin content in the hypothalamic arcuate nucleus in arterial hypertension of different etiologies
}

\author{
O. V. Hancheva, S. V. Tishchenko, T. V. Ivanenko
}

Zaporizhzhia State Medical University, Ukraine

Key words:

hypothalamus, arcuate nucleus, neurotensin, hypertension, rats.

\section{Pathologia} 2018; 15 (2), 176-179

DOI:

10.14739/2310-1237.

2018.2.141399

E-mail:

gancheva@zsmu.pp.ua
The aim of this work is to determine the features of the neurotensin content in the hypothalamic ARC in Wistar rat and SHR strains in arterial hypertension of different etiology: endocrine-salt and essential.

Materials and methods. The study was performed on 24 adult male rats at the age of 13-14 months, weight of 250-270 g, which were divided into three experimental groups of 8 animals each. The $1^{\text {st }}$ group (control) - Wistar rats with normal BP indices (Psys / Pdias $=110 / 75 \pm 5 \mathrm{~mm} \mathrm{Hg}$ ), the $2^{\text {nd }}-$ Wistar rats with endocrine-salt model of hypertension (Psys/Pdias $=145 / 110 \pm 10 \mathrm{~mm} \mathrm{Hg}$ ); the $3^{\text {rd }}-\mathrm{SHR}$ with spontaneous arterial hypertension (Psys $/$ Pdias $\left.=150 / 110 \pm 10 \mathrm{~mm} \mathrm{Hg}\right)$. An immunohistochemical method was used to study the content of neurotensin in the arcuate nucleus, analyzed by digital processing with Image $\mathrm{J}$ and EXCEL-7.0.

Results. Persistent increase in BP is accompanied by an increase in the content and concentration of neurotensin in the hypothalamic ARC, does not depend on the etiology of hypertension and has a compensatory character. In SHR with essential hypertension there is a higher expression of neurotensin in the hypothalamic ARC in comparison with the endocrine-salt model of hypertension, but the number of neurons involved in the synthesis and accumulation of the neurohormone is significantly lower, which characterizes the morphological features of cellular populations in the hypothalamus of the animals of this strain and can play a role in the development and progression of hypertension.
Ключові слова: гіпоталамус, аркуатне ялро, нейротензин, артеріальна гіпертензія, щури.

Патологія. - 2018. T. 15, № 2(43). C. $176-179$

\section{Кількісні характеристики вмісту нейротензину в аркуатному ядрі гіпоталамуса при різних за етіологією артеріальних гіпертензіях}

\section{О. В. Ганчева, С. В. Тіщенко, Т. В. Іваненко}

Мета роботи - встановити особливості вмісту нейротензину в аркуатному ядрі (АрЯ) гіпоталамуса в щурів ліній Wistar i SHR при етіологічно різних артеріальних гіпертензіях (ендокринно-сольовій та есенціальній).

Матеріали та методи. Дослідження виконали на 24 статевозрілих щурах-самцях масою 250-270 г, віком 13-14 місяців, яких поділили на 3 експериментальні групи по 8 тварин у кожній: 1 - контрольна з нормальними показниками АТ (Рс/Рд = 110/75 \pm 5 мм рт. ст.), щури лінії Wistar; 2 - щури лінії Wistar з ендокринно-сольовою моделлю АГ (145/110 \pm 10 мм рт. ст.); 3 - щури лінії SHR зі спонтанною АГ (Рс/Pд = 150/110 \pm 10 мм рт. ст.). Для вивчення вмісту нейротензину в аркуатному ядрі використали імуногістохімічний метод. Надалі дані опрацювали в програмах ImageJ i EXCEL-7.0.

Результати. Стійке підвищення артеріального тиску супроводжується збільшенням вмісту та концентрації нейротензину (HТ) в АрЯ гіпоталамуса й не залежить від етіології АГ, має компенсаторний характер. При есенціальній АГ у щурів лінії SHR визначили вищу експресію HT в АрЯ гіпоталамуса порівняно з ендокринно-сольовою моделлю гіпертензії, але кількість нейронів, залучених у накопичення і синтез нейрогормона, вірогідно менша, що характеризує морфологічну особливість клітинних популяцій гіпоталамуса у тварин цієї лінії та може відігравати роль у розвитку, прогресуванні АГ.

Ключевые слова: гипоталамус, аркуатное яаро, нейротензин, артериальная гипертензия, крысы.

Патология. - 2018. T. 15, № 2(43). C. 176-179

\section{Количественные характеристики содержания нейротензина в аркуатном ядре гипоталамуса при разных по этиологии артериальных гипертензиях}

\section{О. В. Ганчева, С. В. Тищенко, Т. В. Иваненко}

Цель работы - установить особенности содержания нейротензина в аркуатном ядре (АрЯ) гипоталамуса у крыс линий Wistar и SHR при этиологически различных артериальных гипертензиях (эндокринно-солевой и эссенциальной).

Материалы и методы. Исследование проведено на 24 половозрелых крысах-самцах массой 250-270 г, в возрасте 13-14 месяцев, которых поделили на 3 экспериментальные группы по 8 животных в каждой: 1 - контрольная с нормальными показателями АД (Рс/Рд =110/75 55 мм рт. ст.), крысы линии Wistar; 2 - крысы линии Wistar с эндокринно-солевой моделью АГ (145/110 \pm 10 мм рт. ст.); 3 - крысы линии SHR со спонтанной АГ (Рс/Рд = 150/110 \pm 10 мм рт. ст.). Для изучения содержания нейротензина в аркуатном ядре использовали иммуногистохимический метод с последующей цифровой обработкой данных в программах ImageJ и EXCEL-7.0.

Результаты. Стойкое повышение АД сопровождается увеличением содержания и концентрации нейротензина в АрЯ гипоталамуса, не зависит от этиологии АГ и носит компенсаторный характер. При эссенциальной АГ у крыс линии SHR отмечена более высокая экспрессия HT в АрЯ гипоталамуса по сравнению с эндокринно-солевой моделью гипертензии, но при этом количество вовлеченных нейронов в накопление и синтез нейрогормона достоверно ниже, что характеризует морфологическую особенность клеточных популяций гипоталамуса у животных этой линии и может играть роль в развитии и прогрессировании АГ. 
At the present stage of society development the prevalence of cardiovascular diseases has increased, among which arterial hypertension $(\mathrm{AH})$ takes a leading place. So, at the current stage $\mathrm{AH}$ is diagnosed in 972 million people with a tendency to increase in the number of patients. The disease is polyetiologic, however among all diagnosed cases of $\mathrm{AH}$ about $50 \%$ had neurogenic origin. This type of $\mathrm{AH}$ arises as a result of central regulatory mechanisms for arterial blood pressure (BP) violation. [1]. The second leading cause of $\mathrm{AH}$ is the endocrine system pathology [2].

Today it is well known that the central element of arterial BP regulation is the hypothalamus and its nuclei which provide interaction between suprasegmental and segmental centers of the autonomic nervous system, participate in maintenance of an organism homeostasis, endocrine balance and vascular tone [3-4]. Adequate regulation of arterial $\mathrm{BP}$ in changing conditions requires coordination of a hypothalamus with superior and inferior neuroendocrine centers as well as coordination of intrahypothalamic nuclei and structures. Hypothalamic ARC carries out this function due to its topographical features, a large number of projections to other nuclei, a wide range of synthesized neuropeptides in it and also the multireceptor apparatus. Multi-year researches of neuropeptide complexes in hypothalamic various structures have shown their imbalance regardless of the AH etiology, however it has its own particular characteristics depending on a disease etiology and topographical relation of structure [5-6].

Among a wide range of the synthesized neuropeptides in ARC, we have chosen neurotensin (NT), a tridecapeptide that is distributed in various organs and tissues in humans, its highest concentrations are found in the GIT and the CNS. It should be noted that the highest concentration of NT localized in CNS is observed in hypothalamus [7]. The physiological effect of NT is dependent on its concentration and place of action therefore number of authors describe its multidirectional effects. Central injection of NT led to hypothermia, analgesia, relaxation of muscles and decreased arterial pressure [8] whereas NT peripheral action was characterized by vasoconstriction, stimulation of intestine motility, inhibition of hydrochloric acid secretion [9].

\section{The purpose}

The purpose of the work was to determine the features of the neurotensin content in the hypothalamic ARC in Wistar rat and SHR strains in arterial hypertension of different etiology: endocrine-salt and essential

\section{Materials and methods}

The study was performed on 24 adult male rats at the age of 13-14 months, weight of 250-270 g, which were divided into three experimental groups of 8 animals each: the $1^{\text {st }}$ group (control) - Wistar rats with normal BP indices (Psys / Pdias $=110 / 75 \pm 5 \mathrm{~mm} \mathrm{Hg}$ ); the $2^{\text {nd }}-$ Wistar rats with endocrine-salt model (ESM) of hypertension (Psys / Pdias = 145/110 \pm 10 mm Hg), (Ukraine patent № UA 102234); the $3^{\text {rd }}-$ SHR with spontaneous arterial hypertension (Psys / Pdias $=150 / 110 \pm 10 \mathrm{~mm} \mathrm{Hg}$ ). An experimental part of the study was carried out in accordance with the
National «General Ethical Principles of Experiments on Animals» (Ukraine, 2001), approved by the Directive 2010/63/EU, adopted in September 22, 2010, by the European Parliament and Council for the protection of animals used for scientific purposes.

To improve the neuropeptides detection animals underwent the intracerebroventricular injection of colchicine two days prior to removing from the experiment that led to axonal transport violation and promoted local accumulation of neuropeptides in the hypothalamus.

The object of study in experimental animals was the hypothalamus, in $14 \mu \mathrm{m}$ sections of which immunohistochemical study was performed to research the NT expression in ARC. Serial sections of the hypothalamus were incubated with rabbit anti-NT IgG (Santa Cruz Biotechnology, USA), diluted 1:200, for 24 hours at $T$ $=+40^{\circ} \mathrm{C}$ in polymeric chambers, then FITC-conjugated mouse anti-rabbit IgG (Santa Cruz Biotechnology, USA), diluted 1:200, were added for 45 minutes at $\mathrm{T}=+37^{\circ} \mathrm{C}$ and placed in a mixture of glycerol/phosphate buffer (9:1).

Specificity control of antibody binding was carried out in a similar manner, but the sections before the primary antibodies application were incubated with the corresponding blocking peptide (Santa Cruz Biotechnology, USA), diluted 1:50. The sections were examined with ultraviolet microscopy (Axio Imager microscope-M2, Carl Zeiss, Germany) with an excitation wavelength $390 \mathrm{~nm}$, using a filter $38 \mathrm{HE}$ with high emission (Carl Zeiss, Germany). The images were captured using an 8-bit camera AxioCam-ERc5s (Carl Zeiss, Germany) and recorded into computer file. Images analysis was performed semi-automatically using Image $\mathrm{J}$ software with an open source (National Institutes of Health, USA).

For accurate identification of the fluorescence area and thus the structure of ARC a «mask» was applied in which the content of immunoreactive material (IRM) to NT in relative units (Uif), the IRM to NT concentration in $1 \mu \mathrm{m}^{2}\left(\mathrm{Uif} / \mu \mathrm{m}^{2}\right)$ and the IRM to NT specific area (\%) in relation to the "mask" square were calculated. At least 200 fields of view in each series were subjected to study. All experimental data were processed using the software EXCEL 7.0 (Microsoft Corporation, USA). The arithmetic average value of the sample (M), its dispersion and mean error $(\mathrm{m})$ were calculated for all indicators. In order to determine significance of study results differences in the experimental groups, Student's coefficient $(t)$ was used and then definition of differences between samples ( $p$ ) probability and confidence interval of mean by Student's distribution tables were carried out. $P$ value $<0.05$ was considered statistically significant.

\section{Results}

In the present study of distribution of NT in hypothalamic $A R C$ in Wistar rats and SHR strain it has been found that persistent increase in BP was accompanied by stereotype changes in NT expression in etiologically different $\mathrm{AH}$ that was characterized by a significant increase in both IRM content and concentration in SHR by $42 \%$ and $10 \%$; in rats with endocrine-salt hypertension by $40 \%$ and $6 \%$ respectively (Table 1, Fig. 1). 
Table 1. NT expression in hypothalamic ARC in the experimental animal groups $(\mathrm{M} \pm \mathrm{m})$

\begin{tabular}{l|l|l|l|}
\multirow{4}{*}{} & \multicolumn{3}{l}{ Neurotensin } \\
\cline { 2 - 4 } & Immunoreactive material content, Uif & Immunoreactive material concentration, Uif//m ${ }^{2}$ & Immunoreactive material specific area, \% \\
\hline Wistar & $160.144 \pm 3.598$ & $14.969 \pm 0.225$ & $53.418 \pm 0.59$ \\
SHR & $249.249 \pm 8.526^{1}$ & $24.369 \pm 0.741^{1}$ & $46.017 \pm 0.732^{1}$ \\
ESM & $177.708 \pm 3.957^{2}$ & $16.347 \pm 0.362^{2}$ & $55.144 \pm 0.626$ \\
\hline
\end{tabular}

${ }^{1}$ : significant difference of the experimental groups indices $(\mathrm{P}$ value $<0.05)$ in comparison with the control indices; ${ }^{2}$ : significant difference of $\mathrm{SHR}$ strain indices $(\mathrm{P}$ value $<0.05)$ in comparison with endocrine-salt hypertension animal group indices.
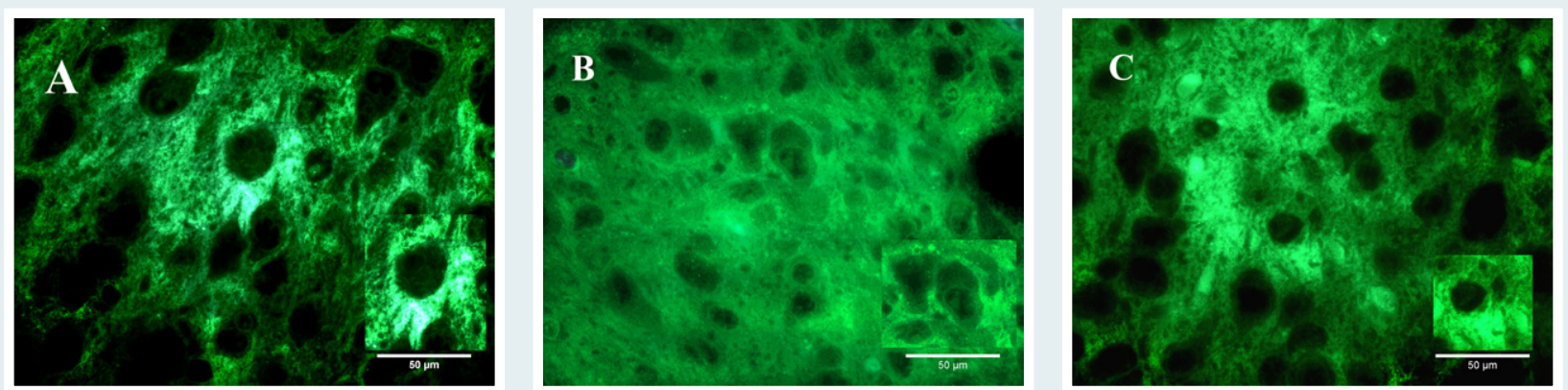

Fig. 1. Distribution of IRM in hypothalamic ARC neurons in the control (A), SHR (B) and endocrine-salt hypertension (C) groups. Reaction of indirect immunofluorescence, magn. $\times 400$.

NT distribution in the ARC structure, which depends on the number of NT expressing and accumulating neurons is associated with the etiology and pathogenesis of $\mathrm{AH}$. Thus, in essential hypertension (SHR strain) IRM to NT specific area was significantly lower by $13 \%$ than in the rats of control group, whereas in animals with endocrine-salt hypertension it was not significantly different from that of the control (Table 1 , Fig. 1).

Comparative analysis of the IRM to NT expression in hypothalamic ARC in rats with $\mathrm{AH}$ showed that the highest content and concentration of neurohormone were observed in the SHR group by $40 \%$ and $50 \%$, respectively higher in comparison with group of animals with endocrine-salt hypertension. Although the IRM to NT specific area was $16 \%$ less (Table 1 ).

\section{Discussion}

The results obtained in the course of study: the IRM to NT expression and content in hypothalamic ARC in rats with $\mathrm{AH}$ raise a number of issues and require deeper analysis. Today there is no clear opinion concerning intrahypotalamic NT concentration, its role and importance in the etiologically different $\mathrm{AH}$. Moreover, even in the well studied SHR strain with genetically determined $\mathrm{AH}$, different researchers show opposite results of NT content, making various hypotheses of its role in hypertension development and progression [10]. So, in the 1980-1990s a group of scientists (A. Shulkes, S. J. Lewis and B. Jarrott) carried out the study and found that NT distribution in the brain of SHR and normotensive rats Wistar-Kyoto (WKY) was similar, its highest concentration (55-75 pmol/g) was in the hypothalamus and the lowest in the cerebellum (3-6 pmol/g). While in comparison with WKY rats SHR had significantly lower levels of NT in the hypothalamus (-17\%), medulla oblongata
(-18\%), pituitary gland (-52\%) and spinal cord (-44\%). The authors explain obtained results by a possible role of NT as a neurotransmitter and its cardiovascular effects following central and peripheral administration. They believe that reduced levels of this peptide may be relevant to its regulatory influence in conditions of increased blood pressure of SHR $[10,11]$. However, we believe that the quantitative indices of any neurohormone expression and prevalence in the brain structures depend on the detection method, state of animals at the time of study (anesthetized or awake), topographical relation to certain nuclear structures of the brain and their function, axonal transport velocity, neurohormone synthesis and accumulation in the neurons.

So, in the described above work, the study of local NT concentrations in the brain structures was carried out using neurohormone extraction from homogenates of the hypothalamus, pituitary gland, cerebellum and the brain stem and then its restoring and identification with radioimmunoassay.

The advantage of our study were $2-3$ days prior intracerebroventricular injection of colchicine in vivo, which contributed to the IRM accumulation in hypothalamic neurons, direct identification of NT in the ARC structure, exclusion of the adjacent hypothalamic structures, which can synthesize or accumulate NT with the help of region of interest selection ("mask") in the quantitative indices calculation.

Thus, the established fact of NT expression increase in hypothalamic ARC with persistent increase in blood pressure, the uniformity of its content changes in etiologically different $\mathrm{AH}$ indicate this neuropeptide involvement in the control and regulation of BP. The same effect of NT was proved by the results of experimental studies, conducted by Rioux and his colleagues who observed that intracerebroventricular injections of NT led to significant hypotension in anesthetized rats [11]. 
The fact of immunoreactive to NT specific area decrease in hypothalamic ARC in SHR strain characterizes the morphological features of hypothalamic cell populations as it has repeatedly been noted by other researchers [12]. Here, the recent morphological studies have shown that the number of neurons in several hypothalamic nuclei (including paraventricular and periventricular optic nuclei) was reduced in SHR strain in comparison with WKY rats. If the reduction in the number of cells is a common phenomenon for SHR, this may explain the significant increase in both concentration and content of local NT levels in hypothalamic ARC in comparison with Wistar rats with endocrine-salt hypertension.

\section{Conclusions}

1. Persistent increase in BP is accompanied by an increase in the content and concentration of NT in the hypothalamic ARC, it does not depend on the etiology of hypertension and has a compensatory character.

2. In SHR with essential hypertension there is a higher expression of neurotensin in the hypothalamic ARC in comparison with the endocrine-salt model of hypertension, but the number of neurons involved in the synthesis and accumulation of the neurohormone is significantly lower, which characterizes morphological features of the hypothalamic cellular populations in the animals of this strain and can play a role in the development and progression of hypertension.

Prospects of the further researches: intracerebroventricular injections of NT are planned with simultaneous BP measuring for the profound study of NT influence on the hypertension development.

Conflicts of Interest: authors have no conflict of interest to declare. Конфмікт інтересів: віАсутній.

Information about authors:

Hancheva O. V., MD, PhD, DSc, Professor, Head

of the Department of Pathological Physiology, Zaporizhzhia State

Medical University, Ukraine.

Tishchenko S. V., MD, Assistant of the Department of Pathological Physiology, Zaporizhzhia State Medical University, Ukraine. Ivanenko T. V., MD, PhD, Associate Professor of the Department of Pathological Physiology, Zaporizhzhia State Medical University, Ukraine.

Відомості про авторів:

Ганчева О. В., А-р меА. наук, професор, зав. каф. патологічної фізіології, Запорізький державний меАичний університет, Україна.

Тіщенко С. В., асистент каф. патологічної фізіології, Запорізький Аержавний медичний університет, Україна.

Іваненко Т. В., канд. меА. наук, Аоцент каф. патологічної фізіології, Запорізький Аержавний медичний університет, Україна.

\section{Сведения об авторах:}

Ганчева О. В., А-р меА. наук, профессор,

зав. каф. патологической физиологии, Запорожский государственный медицинский университет, Украина.

Тищенко С. В., ассистент каф. патологической физиологии, Запорожский государственный медицинский университет, Украина.

Иваненко Т. В., канА. меА. наук, Аоцент каф. патологической физиологии, Запорожский государственный медицинский университет, Украина.
Надійшла Ао редакції / Received: 14.06.2018

Після Аоопрацювання / Revised: 03.07.2018

Прийнято Ао Аруку / Accepted: 06.07.2018

\section{References}

[1] Mozaffarian, D., Benjamin, E. J., Go, A. S., Arnett, D. K., Blaha, M. J., Cushman, M., et al. (2015). Heart disease and stroke statistics-2015 update: a report from the American Heart Association. Circulation, 131(4), e29-322. doi: 10.1161/CIR.0000000000000152.

[2] Gerasimova, A. S., \& Olejnikov, V. E. (2008). Arterial'naya gipertoniya, associirovannaya s metabolicheskim sindromom: osobennosti techeniya i porazheniya organov-mishenej [Arterial hypertension associated with metabolic syndrome: features of the course and lesion of target organs]. Medicinskie nauki. Obzory literatury, 3. [in Russian].

[3] Kawabe, T., Kawabe, K., \& Sapru, H. N. (2012). Cardiovascular Responses to Chemical Stimulation of the Hypothalamic Arcuate Nucleus in the Rat: Role of the Hypothalamic Paraventricular Nucleus. PLOS ONE, 7(9), e45180. doi: 10.1371/journal.pone.0045180.

[4] Chronwall, B. (1985). Anatomy and physiology of the neuroendocrine arcuate nucleus. Peptides, 6(2), 1-11. doi: 10.1016/01969781(85)90128-7.

[5] Littlejohn, N. K., Siel, R. B. Jr., Ketsawatsomkron, P., Pelham, C. J., Pearson, N. A., Hilzendeger, A. M., et al. (2013) Hypertension in mice with transgenic activation of the brain renin-angiotensin system is vasopressin dependent. Physiology Publisher, 304(10), R818-28. doi: 10.1152/ajpregu.00082.2013

[6] Garlow, S. J., Boone, E., Kinkead, B., \& Nemeroff, C. B. (2006). Genetic Analysis of the Hypothalamic Neurotensin System. Neuropsychopharmacology, 31(3), 535-543. doi: 10.1038/sj.npp.1300870.

[7] Merchenthaler, I., \& Lennard, D. E. (1991). The Hypophysiotropic Neurotensin-Immunoreactive Neuronal System of the Rat Brain. Endocrinology, 129(6), 2875-2880. doi: 10.1210/endo-129-6-2875.

[8] Nemeroff, C., Luttinger, D., \& Prange, A. (1980). Neurotensin: central nervous system effects of a neuropeptide. Trends in Neurosciences, 3(9), 212-216. doi: https://doi.org/10.1016/0166-2236(80)90080-6.

[9] Osadchuk, M. A., Osadchuk, A. M., Balashov, D. V., \& Kvetnoy, I. M. (2011). Refrakternaya forma gastroe'zofageal'noj reflyuksnoj bolezni: kliniko-e'ndoskopicheskie, funkcional'nye i morfofunkcional'nye kriteril [The refractory form of gastroesophageal reflux disease: clinical and endoscopical, functional and morphofunctional criteria]. Rossijskij zhurnal gastroe'nterologii, gepatologii, koloproktologii, 21(2), 30-36. [in Russian].

[10] Sumners, C., Phillips, M. I., \& Richards, E. M. (1982). Central pressor action of neurotensin in conscious rats. Hypertension, 4(6), 888-893.

[11] Quirion, R., Rioux, F., Regoli, D., \& St-Pierre, S. (1980). Compound $48 / 80$ inhibits neurotensin-induced hypotension in rats. Life Sciences, 27(20), 1889-1895. doi: 10.1016/0024-3205(80)90435-X.

[12] Nelson, D., \& Boulant, J. (1981). Altered CNS neuroanatomical organization of spontaneously hypertensive (SHR) rats. Brain Research, 226(1-2), 119-130. 